\title{
Language events and virtual communication from the aspect of ethnography communication
}

\begin{abstract}
This research discusses on the history of virtual language from the aspect of ethnography communication. The objectives of the research are to identify the communication component in virtual events, to apply ethnography communication theory virtually and to elaborate the components of communication in the virtual events. This study involves the library research and analysis of texts. It focuses on the Malay virtual events in the Portal Pendidikan Utusan. The instrument to analyse the data is the transcription of the virtual Malay language. The data will analyze the content of the text. This research will be using the ethnography communication theory by Hymes (1972).
\end{abstract}

Keyword: virtual language, ethnography communication 